\title{
Cowpea [Vigna unguiculata (L.) Walp.] Yield Variance and Supported Character
}

\author{
Pratanti Haksiwi Putri ${ }^{1 *}$ Novita Nugrahaeni ${ }^{1}$ \\ ${ }^{I}$ Indonesian Legume and Tuber Crops Research Institute, Indonesia \\ "Corresponding author.Email: pratantihaksiwi@pertanian.go.id
}

\begin{abstract}
Cowpea is an underutilized legume that has been cultivating in Indonesia. But, the availability of cowpea variety is limited. Cowpea breeding program is started with gene source characterization of germplasm. This research aims to study the yield and its supported component variability of cowpea germplasm. One hundred and fifty cowpea accessions were planted using randomized block design with two replications. Observation was done for days of flowering, days of maturity, plant height, number of branches, number of pods per plant, pod length, number of seeds per pod, seed weights per plant, 100 seeds weight, and seed weights per plot. Statistic descriptive, analysis of variance, and was analyzed with MSTAT 1.4 version software, while path analysis was done with SPSS 19 version. Days of flowering was ranged 32-53 das, days of maturity 60-79 das, plant height 16-51.3 cm, number of branches 0-5, number of pods per plant 13-93, pod length 9.1-22.8 cm, number of seeds per pod 12-20, seed weight 7.47-76.17 g per plant, 100 seeds weight 4.19-18.5 g, and seed weight per plot 45.61$346.58 \mathrm{~g}$. There were significant differences between the genotype in leaf length $\mathrm{x}$ width, plant height, pod length, number of pods per plant, weight of 100 seeds, and seed weight per plot. All of the observed characters were correlated highly significant to yield, except days of maturity, leaf length $\mathrm{x}$ width, and pod length which correlated significantly, also number of branches and number of seeds per pod which not correlated significantly to yield. Selection was held for yield character using $20 \%$ selection index and there were 19 accessions selected, with 269.58-326.48 g seed yield per plot.
\end{abstract}

Keywords: cowpea, selection, yield

\section{INTRODUCTION}

Cowpea [Vigna unguiculata (L.) Walp.] is a member of Leguminoceae that has not been cultivated widely in Indonesia. Certain organs such as leaves and seeds can be used as food. The forage and residues substitute $66 \mathrm{~kg}$ urea- $\mathrm{N} / \mathrm{ha}$ and $70 \mathrm{~kg}$ urea$\mathrm{N} /$ ha within urea substitution, and $12 \mathrm{~kg}$ urea- $\mathrm{N} /$ ha and $14 \mathrm{~kg}$ urea-N / ha without urea [1]. Fresh weight and production of mint plant essential oil increased by $23.4 \%$ and $25.2 \%$ by application of cowpea forage. Cowpea forage contributes $30 \mathrm{~kg} \mathrm{~N} /$ ha without fertilizer to mint plantations [2]. This means that cowpeas can also be used as organic matter to increase soil fertility and crop yields thereafter. Intercropping pattern of corn and cowpea as a base crop produces $5.34 \mathrm{t} / \mathrm{ha}$ of maize and a profit of IDR $13,671,000$ / ha with a B / C ratio of 2.05 [3].
Cowpea breeding was initiated in 1991 by Indonesian Legume and Tuber Crops Research Institute (ILETRI) as cowpeas consumption became common in Indonesia. ILETRI has released eight cowpea varieties until 1998 [4]. The assembly of cowpea superior varieties still needs to be done to increase choices diversity for people especially for farmers. Three characters that are taken by farmers in selecting cowpea genotypes are yield, resistance to pests and diseases, and seed coat color. Creamy or white seed coat color is preferably associated with shorter cooking times $[5,6]$.

ILETRI has more than 150 cowpea accessions, in germplasm collection with various characters. According to [7], the seed yields of ILETRI's cowpea 
germplasm collection reached $1.62 \mathrm{t} /$ ha. Seed coat colors consisted of brown (62\%), red (51\%), cream $(18 \%)$, black (14\%), and striated (4\%). A total of 50 cowpea accessions from the ILETRI collection have also been evaluated for resistance to aluminum stress at the germination stage. Seven accessions were known to be tolerant and six accessions were classified as moderate [8]. These various characters and superiority have the potential to become a source of genes in the assembly of superior cowpea varieties in Indonesia.

Characterization of germplasm collections is needed in pre-breeding activities [9]. The purpose of characterization is to identify accessions that have superior character so that they can be used as parents in the breeding program. Therefore, this study aims to characterize and preliminary selection of ILETRI cowpea collections so that they can be developed in breeding activities.

\section{MATERIALS AND METHODS}

\subsection{Materials}

The research material was 150 cowpea accessions from ILETRI germplasm. The research was conducted at the Muneng Agricultural Technology Research and Assessment Installation (ATRAI) in 2017. Experimental design was complete randomized block design with two replications. Each accession was planted in a plot measuring $1.5 \mathrm{~m} \mathrm{x} 4 \mathrm{~m}$, spacing $75 \mathrm{~cm} \times 20 \mathrm{~cm}$.

\subsection{Observation}

Observations were made on days of flowering, days of maturity, leaf area, plant height, number of branches, pod length, number of seed pods ${ }^{-1}$, number of pods plant ${ }^{-1}$, seed weight plant ${ }^{-1}$, weight of one hundred seeds, and seed weight plot $^{-1}$. Qualitative characters observed were hypocotyl color, flower color, growth type, leaf shape, ripe pod color, and seed color.

\subsection{Analysis}

Descriptive and variance analysis, followed by selection with $20 \%$ selection limit, using MSTAT version 1.4 (10) and Microsoft Excel 2010 software. Correlation and path analysis were also carried out to determine the relationship among the characters with the help of SPSS 19 version software [11]. The conclusion of direct and indirect relationship is based on [12].

\section{RESULT AND DISCUSSION}

Descriptive analysis results of 11 cowpea characters in ILETRI collection showed that the fastest days to flowering and maturity were 32 days and 60 days. The latest flowering and maturity age were 53 and 79 days. Flowering age of cowpeas according to [7] was not much different from this study, there were, 33-51 days after sowing (das).

Table 1. Character description in population of 150 cowpea accessions planted in Muneng, 2017

\begin{tabular}{ccccc}
\hline Variable & Minimum & Maximum & Mean & SD \\
\hline X1 & 32.00 & 53.00 & 42.24 & 5.13 \\
X2 & 60.00 & 79.00 & 68.21 & 4.23 \\
X3 & 14.00 & 123.28 & 52.35 & 20.41 \\
X4 & 16.00 & 51.30 & 29.62 & 6.17 \\
X5 & 0.00 & 5.00 & 2.72 & 1.25 \\
X6 & 9.10 & 22.80 & 16.17 & 2.20 \\
X7 & 12.00 & 20.00 & 16.05 & 1.66 \\
X8 & 13.00 & 93.00 & 37.55 & 13.44 \\
X9 & 7.47 & 76.17 & 30.66 & 14.85 \\
X10 & 4.19 & 18.45 & 10.46 & 2.97 \\
X11 & 45.61 & 346.58 & 181.58 & 61.41 \\
\hline
\end{tabular}

Note: X1=days of flowering (das); X2=days of maturity (das); X3=leaf length $\mathrm{x}$ width $\left(\mathrm{cm}^{2}\right) ; \mathrm{X} 4=$ plant height (cm); X5=number of branches; $\mathrm{X} 6=$ pod length $(\mathrm{cm}) ; \mathrm{X} 7=$ number of seed $\operatorname{pod}^{-1} ; \mathrm{X} 8=$ number of pod plant ${ }^{-1} ; \mathrm{X} 9=$ seed weight plant ${ }^{-1}(\mathrm{~g}) ; \mathrm{X} 10=\mathrm{weight}$ of 100 seeds $(\mathrm{g})$; $\mathrm{X} 11=$ seed weight plot $^{-1}\left(\mathrm{~g} / 6 \mathrm{~m}^{2}\right)$ 


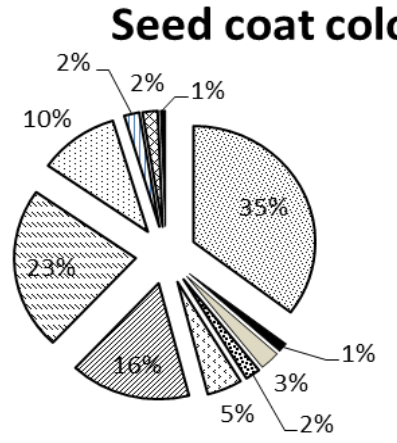

\author{
Red \\ - Dark red \\ $\square$ Red spickled \\ 国 Purple spickled \\ ๑Grey spickled \\ øbrown
}

⿶Cream

\section{Flower colour}

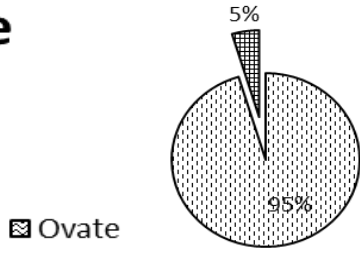

囚 Lanceolate

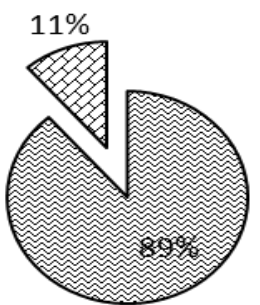

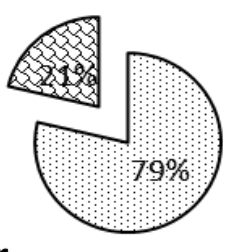

Brown

因 Dark brown

\section{Pod colour}

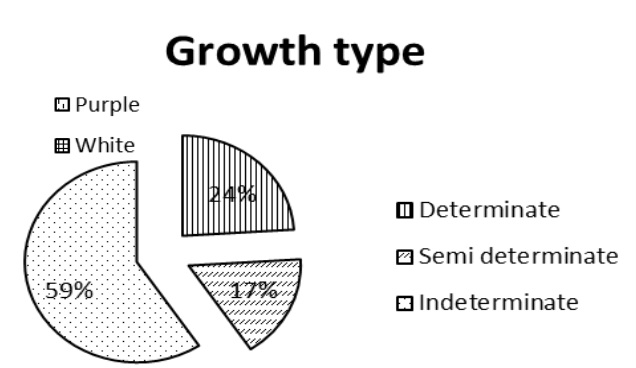

Figure 1. Diagram for five qualitative characters of 150 cowpea accessions planted in Muneng, 2017

The days of maturity ranged from 53-67, which was earlier than this study. Grouping of cowpeas days of maturity was reported by [13] and could be divided into three groups: early maturity ( $<85$ das), medium (85-95 das), and lately (> 95 das). Hereby, the cowpea accessions in this study were early maturing.

Leaf area varied widely from $14 \mathrm{~cm}^{2}$ to 123.28 $\mathrm{cm}^{2}$. Plant height was around $16-51.3 \mathrm{~cm}$, the number of branches could reach 5 branches, and pod production 13 to 93 pods plant ${ }^{-1}$. Average pod length was $16.2 \mathrm{~cm}$ and number of seeds $\operatorname{pod}^{-1}$ was 16 . It was reported by (14) that the shortest plant height was $15.3 \mathrm{~cm}$ and the maximum plant height reached $213.3 \mathrm{~cm}$. The maximum number of branches was 4 , and the maximum number of pods was 34 pods plant $^{-}$ ${ }^{1}$, the maximum length of pod was 33 and the number of seeds pod $^{-1}$ was 18 .

Seed weight plant $^{-1}$ was $76.17 \mathrm{~g}$, while the average seed weight plot $^{-1}$ was $181.58 \mathrm{~g}$. Weight of 100 seeds of cowpeas in this study ranged from 4.19$18.5 \mathrm{~g}$ (Table 1). The weight of 100 seeds reported by (14) was lower, namely $10.77 \mathrm{~g}$.

All of the materials had a green hypocotyl. The seed coat color is very diverse, there are 7 colour variants of the seed coat. Most of the accessions (35\%) had red seed coat. As many as $79 \%$ of accessions had dark brown pod colour. Most of the accessions (89\%) had ovate-shaped leaves and a small proportion (11\%) were lanceolate-shaped. As many as $95 \%$ of accessions have purple flower, while the rest have white flowers. The growth types varied between indeterminate $(59 \%)$, semi determinate (17\%), and determinate (24\%) (Figure 1). According to (7), similar descriptions was reported for six qualitative characters of cowpea in the ILETRI collection. The red seed coat is the second largest after brown. Ovate leaves are more numerous than lanceolate, and most of the accessions have purple flowers.

Replication caused very significant differences in days of maturity, number of branches, pods length, number of pods plant ${ }^{-1}$, seeds weight plant $^{-1}$, weight of 100 seeds, and seeds weight plot $^{-1}$. This may be due to micro-environment differences among replication. Significant differences among the genotypes were in leaf area, plant height, pod length, number of pods plant ${ }^{-1}$, weight of 100 seeds, and seeds weight plot $^{-1}$ (Table 2). Leaf area difference was caused by varied leaves-shape of cowpea accessinon. While plant height differences may be caused by differences in growth types. Indeterminate cowpea has a higher plant than determinate cowpea. Indeterminate growth type also has the potential to harvest more than once so that the seed weight plant $^{-1}$ and plot $^{-1}$ may be higher than the determinate type. 
Table 2. Analysis of variance for 11 characters of 150 cowpea accessions planted in Muneng, 2017

\begin{tabular}{|c|c|c|c|c|c|}
\hline \multirow{3}{*}{$\begin{array}{c}\text { Variable } \\
\text { X1 }\end{array}$} & \multicolumn{4}{|c|}{ Mean square } & \multirow{3}{*}{$\begin{array}{c}\text { CV (\%) } \\
10.5\end{array}$} \\
\hline & \multicolumn{2}{|c|}{ Replication } & \multicolumn{2}{|c|}{ Genotype } & \\
\hline & 2694.0 & $* *$ & 14.82 & ns & \\
\hline $\mathrm{X} 2$ & 0.0 & ns & 35.87 & ns & 0.0 \\
\hline $\mathrm{X} 3$ & 0.1 & ns & 0.042 & $* *$ & 8.9 \\
\hline $\mathrm{X} 4$ & 130.0 & $*$ & 46.94 & $* *$ & 18.0 \\
\hline $\mathrm{X} 5$ & 13.2 & $* *$ & 1.12 & ns & 36.4 \\
\hline X6 & 32.2 & $* *$ & 6.94 & $* *$ & 10.0 \\
\hline $\mathrm{X} 7$ & 0.0 & ns & 5.55 & ns & 0.0 \\
\hline $\mathrm{X} 8$ & 6384.9 & $* *$ & 216.8 & $* *$ & 27.0 \\
\hline $\mathrm{X} 9$ & 33323.3 & $* *$ & 120.2 & ns & 32.4 \\
\hline $\mathrm{X} 10$ & 1685.1 & $* *$ & 5.3 & $* *$ & 10.2 \\
\hline $\mathrm{X} 11$ & 519697.3 & $* *$ & 2620.5 & ** & 21.0 \\
\hline
\end{tabular}

Note: $\mathrm{X} 1=$ days of flowering (das); X2=days of maturity (das); $\mathrm{X} 3=$ leaf length $\mathrm{x}$ width $\left(\mathrm{cm}^{2}\right) ; \mathrm{X} 4=$ plant height $(\mathrm{cm}) ; \mathrm{X} 5=$ number of branches; X6 $=$ pod length $(\mathrm{cm}) ; X 7=$ number of seed pod $^{-1}$;

$\mathrm{X} 8=$ number of pod plant ${ }^{-1} ; \mathrm{X} 9=$ seed weight plant $^{-1}(\mathrm{~g})$;

$\mathrm{X} 10=$ weight of 100 seeds $(\mathrm{g}) ; \mathrm{X} 11=$ seed weight $\mathrm{plot}^{-1}\left(\mathrm{~g} / 6 \mathrm{~m}^{2}\right)$

Phenotype's variance (PV) was greater than genotypes variance $(\mathrm{GV})$ except for days of flowering, days of maturity, and number of seeds $\operatorname{pod}^{-1}$ (Table 3 ). The value of genotype variance in a one-factor complete randomized block design was obtained from the difference between genotype mean square and error mean square of a character in the population per replication. Genotypes mean square in analysis of variance is a combination of genetic and environmental factors. Environmental factors need to be separated first so that genotype variance reflects the population genetic diversity [15].

In line with the variance value, the phenotypic coefficient of variance (PCV) was also greater than the genetic coefficient of variance (GCV) except for the days of maturity and number of seeds pod ${ }^{-1}$. Days of flowering GCV value could not be estimated because the genotype variance was minus (Table 3 ). $\mathrm{PCV}$ values that are greater than GCV values imply that the diversity of certain characters in the population is caused by the influence of environmental factors. GCV value which is greater or similar with PCV value imply genetic factors influence to the character diversity.

Days of maturity and number of seeds pod $^{-1}$ have similar genetic and phenotypic variance, as well as PCV and GCV, so that the broad sense heritability value is 1 . The broad sense heritability (Hbs) explains the proportion of genetic and environmental factors influence. The higher heritability value of a character, the higher genetic factors influence and inheritance of those character become easier. Heritability values are grouped according to $(16)$ in $(17)$ hereby, low $(<0.2)$, medium $(0.2<\mathrm{H}<0.5)$, and high $(>0.5)$. Characters with high genetic variance, GCV and Hbs have the potential to become the selection criteria. Days of flowering and number of seeds pod $^{-1}$ had the potential to become selection criteria because they had high genetic variance values, GCV and Hbs (Table 3).

Table 3. Genetic parameter estimation of 150 cowpea accessions planted in Muneng, 2017

\begin{tabular}{ccccccc}
\hline Variable & $\mathbf{V g}$ & $\mathbf{V p}$ & $\mathbf{V e}$ & $\mathbf{H b s}$ & $\mathbf{P C V}$ & $\mathbf{G C V}$ \\
\hline X1 & -2.50 & 17.32 & 19.82 & -0.14 & 9.85 & - \\
X2 & 17.94 & 17.94 & 0.00 & 1.00 & 6.21 & 6.21 \\
X3 & 0.01 & 0.03 & 0.02 & 0.29 & 0.34 & 0.19 \\
X4 & 9.20 & 37.75 & 28.55 & 0.24 & 20.74 & 10.24 \\
X5 & 0.04 & 1.09 & 1.05 & 0.03 & 38.30 & 6.88 \\
X6 & 2.18 & 4.77 & 2.59 & 0.46 & 13.50 & 9.12 \\
X7 & 2.78 & 2.78 & 0.00 & 1.00 & 10.38 & 10.38 \\
X8 & 56.87 & 159.95 & 103.08 & 0.36 & 33.68 & 20.08 \\
X9 & 10.83 & 109.37 & 98.54 & 0.10 & 34.11 & 10.73 \\
X10 & 2.08 & 3.22 & 1.14 & 0.65 & 17.14 & 13.77 \\
X11 & 581.01 & 2039.54 & 1458.53 & 0.28 & 24.87 & 13.27 \\
\hline
\end{tabular}

Note: X1=days of flowering (das); X2=days of maturity (das); X3=leaf length $\mathrm{x}$ width $\left(\mathrm{cm}^{2}\right)$; X4=plant height (cm); X5=number of branches; $\mathrm{X} 6=$ pod length $(\mathrm{cm}) ; \mathrm{X} 7=$ number of seed $\operatorname{pod}^{-1} ; \mathrm{X} 8=$ number of pod plant ${ }^{-1} ; \mathrm{X} 9=$ seed weight plant ${ }^{-1}(\mathrm{~g}) ; \mathrm{X} 10=$ weight of $100 \mathrm{seeds}(\mathrm{g})$; $\mathrm{X} 11=$ seed weight $\operatorname{plot}^{-1}\left(\mathrm{~g} / 6 \mathrm{~m}^{2}\right)$ 
Table 4. Path analysis for 11 characters of 150 cowpea accessions planted in Muneng, 2017

\begin{tabular}{|c|c|c|c|c|c|c|c|c|c|c|c|c|}
\hline \multirow{2}{*}{$\mathbf{X i}$} & \multirow{2}{*}{$\mathbf{P}$} & \multicolumn{11}{|c|}{ Indirect effect through } \\
\hline & & $\mathbf{X 1}$ & $\mathbf{X} 2$ & $\mathbf{X 3}$ & $\mathbf{X} 4$ & X5 & X6 & $\mathbf{X} 7$ & X8 & X9 & X10 & X11 \\
\hline $\mathrm{X} 1$ & 0.08 & - & $0.21^{* *}$ & -0.05 & 0.04 & -0.04 & 0.01 & -0.09 & $0.16^{* *}$ & $0.34^{* * *}$ & $0.44^{* *}$ & $0.317^{* * *}$ \\
\hline $\mathrm{X} 2$ & -0.13 & $0.21^{* *}$ & - & -0.11 & 0.09 & 0.005 & -0.08 & 0.06 & -0.06 & -0.08 & -0.06 & $-0.145^{*}$ \\
\hline $\mathrm{X} 3$ & -0.03 & -0.05 & -0.11 & - & $0.24^{* *}$ & -0.1 & $0.18^{* *}$ & 0.09 & $0.17^{* *}$ & $0.26^{* *}$ & $0.2^{* *}$ & $0.129^{*}$ \\
\hline $\mathrm{X} 4$ & 0.07 & 0.039 & 0.09 & $0.24^{* *}$ & - & 0.06 & -0.06 & 0.01 & $0.23^{* *}$ & $0.3^{* *}$ & 0.09 & $0.184^{* *}$ \\
\hline $\mathrm{X} 5$ & 0.002 & -0.04 & 0.005 & -0.1 & 0.06 & - & $\begin{array}{l}- \\
0.19^{* *}\end{array}$ & -0.11 & 0.06 & -0.1 & $-0.28^{* *}$ & -0.102 \\
\hline X6 & -0.04 & 0.01 & -0.08 & $0.18^{* *}$ & -0.06 & $-0.2^{* *}$ & - & 0.31 & -0.08 & $0.12^{*}$ & $0.4^{* * *}$ & $0.119^{*}$ \\
\hline $\mathrm{X} 7$ & -0.01 & -0.09 & 0.06 & 0.09 & 0.01 & -0.11 & 0.31 & - & $\begin{array}{l}- \\
0.28^{* * *}\end{array}$ & -0.004 & $0.13^{*}$ & -0.015 \\
\hline X8 & 0.05 & $0.16^{* *}$ & -0.06 & $0.17^{* *}$ & $0.23^{* *}$ & 0.06 & -0.08 & $-0.23^{* *}$ & - & $0.72^{* *}$ & $0.13^{*}$ & $0.333^{* *}$ \\
\hline X9 & 0.28 & $0.34^{* *}$ & -0.08 & $0.26^{* *}$ & $0.3^{* *}$ & -0.09 & $0.12^{*}$ & -0.004 & $0.72^{* *}$ & - & $0.63^{* *}$ & $0.575^{* *}$ \\
\hline $\begin{array}{c}\mathrm{X} 1 \\
0\end{array}$ & 0.34 & $0.44^{* *}$ & -0.06 & $0.19^{* *}$ & 0.09 & $-\overline{0}^{* 28^{* *}}$ & $0.39^{* *}$ & $0.13^{*}$ & $0.13^{*}$ & $0.63^{* *}$ & - & $0.548^{* *}$ \\
\hline
\end{tabular}

Note: X1=days of flowering (das); X2=days of maturity (das); X3=leaf length $\mathrm{x}$ width $\left(\mathrm{cm}^{2}\right)$; X4=plant height (cm); X5=number of branches; $\mathrm{X} 6=$ pod length $(\mathrm{cm}) ; \mathrm{X} 7=$ number of seed $\operatorname{pod}^{-1} ; \mathrm{X} 8=$ number of pod plant ${ }^{-1} ; \mathrm{X} 9=$ seed weight plant ${ }^{-1}(\mathrm{~g}) ; \mathrm{X} 10=$ weight of 100 seeds $(\mathrm{g})$; $\mathrm{X} 11=$ seed weight plot $^{-1}\left(\mathrm{~g} / 6 \mathrm{~m}^{2}\right) ; \mathrm{P}=$ direct effect through

GCV is categorized as high if it is more than 2SD (standard deviation) [18]. Pod length character had high heritability values, but low and medium values of genetic variance and GCV. The weight of 100 seeds could be used as selection criteria because it had high heritability and GCV even though the genetic variance was low. Number of pods plant ${ }^{-1}$ had a wide genetic variation despite medium heritability. Thus, the selection criteria that could be used based on this study are days of flowering, number of seeds $\operatorname{pod}^{-1}$, number of pods plant ${ }^{-1}$, and weight of 100 seeds. According to [19] reported that number of clusters and number of pods plant ${ }^{-1}$ could be used as secondary characters in cowpea selection because they had high direct effect based on path analysis. It wa also stated by [20] that number of pods plant ${ }^{-1}$ supported by pod diameter had a significant positive effect on dry weight plant $^{-1}$.

Table 5. Selected accession based on $20 \%$ selection intensity in seed weight plot $^{-1}$ character of 150 cowpea accessions planted in Muneng, 2017

\begin{tabular}{|c|c|c|c|c|}
\hline \multicolumn{2}{|c|}{ Accession (MLGU) } & Variable & Min. & Max. \\
\hline \multicolumn{2}{|c|}{$\begin{array}{l}\text { MLGU 17001; MLGU 17004; MLGU 17015; MLGU } \\
\text { 17018; MLGU 17039; MLGU 17050; MLGU 17061; } \\
\text { MLGU 17070; MLGU 17074; MLGU 17078; MLGU } \\
\text { 17085; MLGU 17090; MLGU 17096; MLGU 17118; } \\
\text { MLGU 17160; MLGU 17171; MLGU 17177; MLGU } \\
\text { 17180; KT 9 }\end{array}$} & Days of flowering (das) & 60.00 & 76.00 \\
\hline \multicolumn{2}{|c|}{ Qualitative character } & $\mathrm{LxW}\left(\mathrm{cm}^{2}\right)$ & 30.10 & 105.60 \\
\hline Hipocotyl & green & Plant height $(\mathrm{cm})$ & 26.33 & 43.67 \\
\hline Flower colour & purple, white & Pod length $(\mathrm{cm})$ & 13.90 & 19.90 \\
\hline Growth type & ID-D & Pods plant ${ }^{-1}$ & 24.00 & 78.00 \\
\hline Leaf shape & almost all ovate & Seeds weight plant $^{-1}(\mathrm{~g})$ & 23.85 & 76.17 \\
\hline Mature pod colour & almost all brown & Weight of 100 seeds $(\mathrm{g})$ & 7.97 & 15.71 \\
\hline Seed coat colour & $\begin{array}{l}\text { white, cream, brown, red, red } \\
\text { spickled, grey spickled, mix }\end{array}$ & Seed weight plot ${ }^{-1}\left(\mathrm{~g} / 6 \mathrm{~m}^{2}\right)$ & 269.60 & 346.58 \\
\hline
\end{tabular}


Seed weight plot $^{-1}$ had medium heritability values (Hbs = 0.28), but genetic variance and GCV were high (581.01 and 13.27). Yield characters generally have low heritability values and are related to other characters. Therefore, plant selection to obtain genotypes that are superior in yield could be done through other characters as selection criteria.

Path analysis was conducted to determine relationship among the characters, especially yield character. Conclusions are made based on [12]. Days of maturity and number of seeds pod $^{-1}$ had almost similar value between correlation and direct effect. So, it would be effectively used as a selection criterion. Days of flowering had an indirect effect on seed weight plot $^{-1}$ through days of maturity. Plant height had an indirect effect through leaf area. Number of branches and weight of 100 seeds had an indirect effect on weight of seeds plot $^{-1}$ through pod length. Meanwhile, the number of pods plant ${ }^{-1}$ and weight of 100 seeds had an indirect effect throught number of pods (Table 4).

Selection was carried out for 150 cowpea accessions based on the character of seed weight plot $^{-}$ ${ }^{1}$ and $20 \%$ selection intensity. The selection limit for seed weight plot $^{-1}$ is $267.5 \mathrm{~g}$, accessions with seed weight plot $^{-1}$ less than that value were not selected. The accessions obtained were 19 accessions with descriptions listed in Table 5.

The selected accessions had a green hypocotyl. Purple flower color except MLGU 17180. Mostly ovate-shaped leaf except MLGU 17004 which lanceolate. Seed's coat colour ranges from white to mixed. MLGU 17070, and MLGU 17180 had white seeds, as well as MLGU 17015, MLGU 17039, MLGU 17061, MLGU 17118, and MLGU 17118 with cream-colored seeds that had the potential to be liked by public or industry as food raw materials.

Selected accessions had higher seed weight plot $^{-1}$ than improved varieties except KT 9. Seems that weight of 100 seeds and number of pods plant ${ }^{-1}$ were causing factors the high value of seed weight plot $^{-1}$. Accessions MLGU 17118 and MLGU 17180 had lower weight of 100 seeds value than other accessions, i.e. $9 \mathrm{~g}$ and $8 \mathrm{~g}$. However, both accessions had a large number of pods plant ${ }^{-1}$, i.e. 72 and 78 . This is in line with the path analysis results, the weight of 100 seeds and number of pods plant ${ }^{-1}$ could be used as selection criteria to support seed weight plot $^{-1}$.

\section{CONCLUSION}

ILETRI's cowpea germplasm collections have various characters, especially in seed coat colour. Most of them have an indeterminate growth type with an average seed weight plot $^{-1}$ ranging from $45.6 \mathrm{~g}$ $346.58 \mathrm{~g}$. Selection to obtain high seed weight plot $^{-1}$ could be carried out using number of pods plant ${ }^{-1}$ and weight of 100 seeds character. Both characters have high value of genetic variance, GCV, and broad sense heritability. These two characters have an indirect effect on seed weight plot $^{-1}$ through number of seeds $\operatorname{pod}^{-1}$. Nineteen accessions were selected using 267.5 $\mathrm{g}$ seed weight plot $^{-1}$ as selection limit. The selected accessions had a higher seed weight plot $^{-1}$ than released varieties except KT 9.

\section{ACKNOWLEDGMENT}

We gratitude to Indonesian Agency of Agricultural Research and Development through Indonesian Legume and Tuber Crops Research Institute as the funders, Sunoto, and Sugianto as field technician during the research.

\section{REFERENCES}

[1] P.S. John, R.K. Pandey, R.J. Buresh, et al., Nitrogen contribution of cowpea green manure and residue to upland rice, Plant soil 142 (1992) 53-61.

DOI: https://doi.org/10.1007/BF00010174

[2] M. Singh, A. Singh, S. Singh, R.S. Tripathi, A.K. Singh, D.D. Patra, Cowpea (Vigna unguiculata L. Walp.) as a green manure to improve the productivity of a menthol mint (Mentha arvensis L.) intercropping system, Industrial Crops and Products 31 (2) (2010) 289-293.

DOI: https://doi.org/10.1016/j.indcrop.2009.11.004

[3] M.P. Sirappa, Syamsuddin, Peningkatan produktivitas Jagung Lokal melalui perbaikan pola tanam pada lahan kering di Kabupaten Maluku Tengah (Increasing Local Maize productivity through improved cropping patterns on dry land in Central Maluku Regency), Prosiding Seminar Nasional Serealia (Proceeding of Cerealia National Conference), IAARD Press, Maros, 2015, pp. 238-247. ISBN: 978-979-8940-40-8

[4] A. Kasno, A. Winarto, Kacang Tunggak (Cowpea), Monograf Balitkabi (ILETRI's Monograph), IAARD Press, 1998.

[5] W. Quaye, K. Adofo, Y.E. Madode, A. Abizari, Exploratory and multidisciplinary survey of the 
cowpea network in Tolon-Kumbungu District of Ghana: a food sovereignty perspective, African Journal of Agricultural Research 4(4) (2009) 311-320.

[6] K.F. Egbadzor, S.K. Offei, E.Y. Danquah, D.A. Kotey, D.K. Gamedoagbao, M. Dadoza, M. Yeboah, K. Ofori, Farmer participation in selection within segregating populations of cowpea in Volta Region, Ghana, Agriculture \& Food Security 4(17) (2015). DOI: https://doi.org/10.1186/s40066-015-0037-1

[7] Trustinah, A. Kasno, M.J. Mejaya, Keragaman sumber daya genetik Kacang Tunggak (cowpea's genetic resource diversity), Jurnal Penelitian Pertanian Tanaman Pangan (Journal of Agricultural Crop Research) 1 (2) (2017) 165-172.

[8] Trustinah, Toleransi genotipe Kacang Tunggak di lahan kering masam (Cowpea genotype tolerance in dry acid soil), in: (Eds.), Prosiding Simposium Peripi VIII Komda Jatim (Proceeding of $8^{\text {th }}$ PERIPI Komda Jatim Symposium), IAARD Press, Malang, 2011, pp. 90-97. ISBN: 978-602-98482-0-5. [In Bahasa Indonesia]

[9] Asadi, P. Lestari, N. Dewi, Pra-pemuliaan aneka kacang dalam mendukung proses pemuliaan untuk perakitan varietas unggul baru (legumes pre-breeding to support breeding process for new improved variety), AgroBiogen 12 (1) (2016) 51-62. [In Bahasa Indonesia]

[10] Michigan State University, MSTAT-C, A microcomputer program for the design, management, and analysis of agronomic research experiments, Michigan State University, 1990.

[11] IBM Corp, IBM SPSS Statistics for Windows, Version 19.0, IBM Corp, Armonk, New York, 2010.

[12] R.K. Singh, B.D. Chaudhary, Biometrical methods in quantitative genetic analysis, Kalyani Publishers, 1979.

[13] M. Makanur, V.K. Deshpande, B.S. Vyakaranahal, Characterisation of cowpea genotypes based on quantitative descriptors, The Bioscan 8 (4) (2013) 1183-1188.

[14] M. Setyowati, Minantyorini, Keragaman Karakter agronomis sumber daya genetik Kacang Tunggak (Vigna unguiculata [L.] Walp.) koleksi bank gen bb biogen (agronomic character diversity of cowpea genetic resources in ICABIOGRAD gene bank), Buletin Plasma
Nutfah (Bulletin of Genetic Resource) 22 (1) (2016) 41-48.

[15] H. Kuswantoro, R. Artari, W. Rahajeng, E. Ginting, A. Supeno, Genetic variability, heritability, and correlation of some agronomical characters of soybean varieties, Biosaintifika 10 (1) (2018) 9-15. DOI: https://doi.org/10.15294/biosaintifika.v10i1.110 $\underline{14}$

[16] K.S. McWhirter, Breeding of cross-pollinated crops: selection methods for improving cross pollinating plant species, in: R. Knight (Eds.), Plant Breeding, Academic Press Pty. Ptd., Brisbane, 1979.

[17] A. Sulistyo, Purwantoro, K.P. Sari, Correlation, path analysis and heritability estimation for agronomic traits contribute to yield on Soybean, in: International Symposium on Food and Agrobiodiversity (ISFA), Semarang, Indonesia, IOP Conferences Series: Earth and Environmental Science $102 \quad$ (2017). DOI: https://doi.org/10.1088/1755-1315/102/1/012034

[18] H. Kuswantoro, Genetic variability and heritability of acid-adaptive soybean promising lines, Biodiversitas 18 (1) (2017) 378-382. DOI: https://doi.org/10.13057/biodiv/d180148

[19] Mastur, M. Setyowati, D.N. Susilowati, Hubungan karakter fenotipik dan hasil biji plasma nutfah Kacang Tunggak [Vigna unguiculata (L.) Walp.] menurut analisis lintasan (yield and phenotypic character correlation of cowpea [Vigna unguiculata (L.) Walp.] genetic resources according to path analysis), Berita Biologi: Jurnal Ilmu-ilmu Hayati (Biological News: Journal of Life Sciences), 17 (2) (2018) 215-221. DOI: https://doi.org/10.14203/beritabiologi.v17i2.226 2. [In Bahasa Indonesia]

[20] B. Mustainnah, L. Ujianto, Sudirman, Kajian keterkaitan antar sifat kuantitatif keturunan hasil persilangan antara spesies Kacang Tunggak dengan Kacang Panjang (intra-quantitative character correlation study of the offspring of cowpea and common bean), Crop Agro, Scientific Journal of Agronomy 9 (1) (2016) 6266. EISSN: 26215748. [In Bahasa Indonesia] 